prices and greater reliance on oil imports. He said he was looking forward to the opportunity to formulate his own energy policy, in an atmosphere devoid of crisis. Though he hasn't been too specific about his proposals, Carter has since suggested several times that he wants to see more emphasis on conservation, more spending on solar energy, and more reliance on coal. He has also attacked the Ford Administration's plans to push development of a synthetic fuels industry.

The chief difference between the
Carter and Ford energy policies lies in the area of nuclear power. In a statement made to a United Nations conference last May, Carter suggested that dependence on nuclear power should be held to the minimum necessary, and he has said that he would reassess the priority being given to the liquid metal fast breeder reactor-the most expensive single energy research and development project supported by the Ford administration. He has, however, stopped short of calling for a moratorium on nuclear power, and he refused to support the California initiative calling for a virtual halt in the development of nuclear power there. (The initiative was defeated in a state-wide referendum last June.)

As election day approaches, science and technology are unlikely to figure very prominently, simply because they do not figure very prominently among the issues about which people are concerned.

If that is a source of encouragement for scientists, it is largely because of the prestige they enjoy.
AfTER a series of unexpected and often bizarre delays, the newly-recreated White House Office of Science and Technology Policy (OSTP) is finally getting down to business, four months after it was legislated into existence and-if the opinion polls are to be believed-only a few weeks before the Ford administration is scheduled to make its political exit. Even though the administration's days may be numbered in double figures, however, OSTP is being established as if its working arrangements will endure well beyond next January's Presidential inauguration.

H. Guyford Stever, who heads the office and who also holds the title of Science Adviser to the President, said in an interview last week, "I'm not expecting a change of administration. And neither is the President". Accordingly, he is busy recruiting staff, hiring consultants and establishing committees, which means that Jimmy Canter, if he is elected, will inherit a functioning science policy office and some top-level committees whose members would be difficult to replace.

Although legislation establishing the office was signed into law by President Ford on May 11, after taking more than a year to pass through Congress, the OSTP's debut was delayed by an unexpected dispute over the appointment of a director. It had long been rumoured that Ford would nominate Simon Ramo, head of the giant aerospace and defence consortium TRW, as his science adviser and director of OSTP. But the nomination was never made, apparently because Senator Kennedy's office insisted that Ramo would have to divest his holdings in TRW before the Senate would confirm his appointment. Ramo decided that, since the polls all pointed to a resounding Ford defeat in November, it wasn't worth the price to be a science adviser for only a few months. Attention then turned to Guy Stever.

An aerospace engineer and former President of Carnegie-Mellon University, Stever has been Director of the National Science Foundation (NSF) since 1972 and part-time White House Science Adviser since mid1973, when Mr Nixon scrapped the old Office of Science and Technology and consigned some of its functions to the NSF. Stever would therefore seem a logical choice for the full-time post of Presidential Science Adviser. But, when news of his impending nomination filtered out, four rightwing Republican Senators warned Ford that they would oppose the appointment. Led by Senator Jesse

\section{Man at the top}

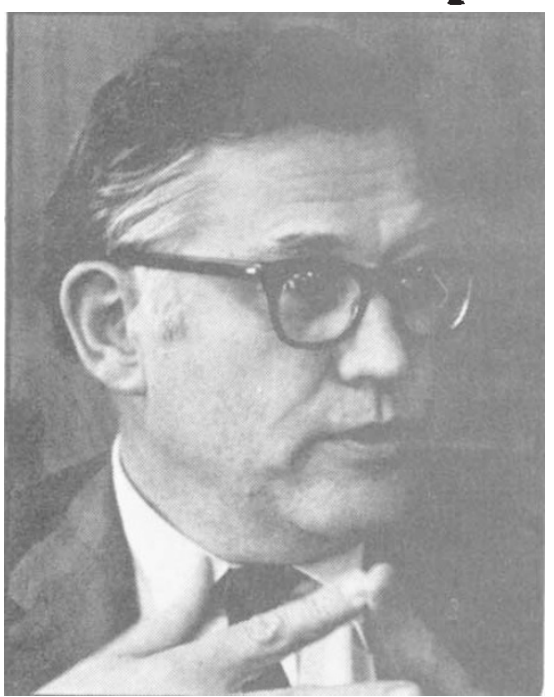

H. Guyford Stever

Helms, they issued a statement critioising Stever's stewardship of the NSF, resurrecting many of the disputes which have swirled around the NSF's education programmes for the past year.

The opposition surfaced while Ford was locked in his neck-and-neck with Ronald Reagan for the Republican nomination. Stever, mindful of the fact that Ford was trying to steer clear of fights with the party's right wing, suggested that his nomination be reconsidered and the matter was put on the back burner for nine weeks. Then, when Ford had the nomination virtually locked up, Stever's nomination was sent to the Senate early in August and swiftly approved with only token opposition.

Stever said last week that he agreed to take on the assignment with the understanding that he wouldn't remain long after January, no matter which administration takes office.

The legislation establishing OSTP also sets up a top-level advisory committee, consisting of between 8 and 14 people drawn from a variety of fields, which will conduct a two-year investigation of federal science support and priorities. One of Stever's first acts was to recommend that Ramo be appointed chairman of that committee, a suggestion which Ford promptly accepted. The other members will be appointed later this month. (Ramo's appointment, incidentally, will present an interesting situation if Carter becomes President, for Ramo was a co-chairman in 1972 of a committee of scientists and engineers supporting the candidacy of Richard Nixon.)

Stever has begun to staff the office with people drawn from NSF's science policy office and a few individuals on secondment from other government agencies. In addition, he has appointed two senior policy consultants, William Nierenberg, Director of the Scripps Institution of Oceanography, and Donald Kennedy, Chairman of the Program in Human Biology at Stanford University. Both will devote half their time to OSTP, assisting in the development of policy studies on biological and environmental issues. Other consultants, Stever indicated, will be called upon as needed.

Asked last week what he considers as OSTP's chief goal, Stever said, "some scientists think that the goal should be to increase the support for science, but they are mistaken. The important thing is to establish an easy relationship at the top level of our government for the scientific community to have an input" into national policy. Colin Norman 